not called science. It is an intellectual act, such as everyone performs when he defines a plant, a mineral, or a commodity. The combination of the symptoms and definition of the disease is, in fact, an important element of the physician's art, and must be included in every course of instruction. Still "Eines schickt sich nicht. für Alle."

When Cuvier determined to what primeval animal a bone found buried in the earth must have belonged, it was only a definition; yet no one will hesitate to rank it amongst the noblest exercises of the human intellect. So, too, the diagnoses of distinguished masters may be ranked with the greatest achievements of medical investigators. To forbid such masters to teach at the bedside because many students crowd about them and disturb the patient, would be absurd. The instruction of such masters is, however, fit only for connoisseurs. For the uncultivated taste of the beginner it is unsuited. If it is besides so diluted as, with a large number of students, must invariably be the case, according to an unalterable law, it entirely loses its value. If, then, the founders of hospitals or their administrators would diminish to a certain definite and very low standard the number of students who, at one time, should be allowed to enjoy the privilege of instruction in a hospital ward, they would certainly do no injury to the interests of education. On the contrary, if liberal in other respects, they would, by such limitation, further these interests.

In what shall this liberality consist? Simply in this, that all available space in the hospital shall be open for the purposes of instruction, and that as many teachers shall be admitted as is consistent with a proper classification of the patients. We say admitted, and this is really the fittest expression, for there is not the smallest doubt that always and everywhere the ablest men would be eager to accept the place of teacher. The intellectual stimulus which an able physician derives from association with a school and intercourse with young men, and the moral support which a situation as instructor gives him in regard to his patients, are sufficient compensations for the required expenditure of time.

The physicians and surgeons who at present have large amounts of material at their disposal in large hospitals, would certainly not be willing to support such a system of division. They would complain that they are deprived of the possibility of attaining great skill. There is some truth in this objection. It is a benefit to mankind when a surgeon, by extensive practice, attains superior skill in the performance of certain operations. But the advantage which a few derive from his technical skill is counterbalanced by the loss which the rest sustain from the superficial manner in which they are passed over with a mere glance. In such a hospital more things are overlooked than one would imagine; and the pupils profit far less from the skill of the teacher than they lose from the superficiality of the teaching. It is, moreover, untrue that skill is likely to suffer from a further division of material. We have examples of great operators who never occupied a position in a hospital. Nor can it be doubted that the greater the number of those to whom the opportunity is given of proving their skill, the greater will be the numter of skilful surgeons.

In the plan here proposed, many readers may see only what is already introduced in England, that is, small schools for the special study of medicine. The writer of this article is, however, far from speaking in behalf of schools of this kind. Such schools are fit only for the production of craftsmen; and medical men, though they must be craftsmen, must not be mere craftsmen. Such small special schools can serve only as preparatory appendages to the larger educational bodies, that is to say, to the Universities, whose function it is to foster the sciences for their own sakes.

Every medical student ought to obtain his education in general physical science and special medical science at the University; and while doing so he must acquire the art of medicine in a hospital, just as the young botanist must study in the field at the same time that he attends lectures.

The small Universities in Germany answer both purposes to an approximate degree. There one finds excellent schools with so few students that they can obtain both the higher scientific education and drill at once. To approach towards such circumstances, without giving up the great advantages which large schools offer for the development of science, is the end towards which we must strive.

S. STRICKER

\section{POLARISATION OF THE CORONA}

$A \mathrm{~S}$ this forms one of the most important questions to A be settled during the coming Eclipse, it becomes desirable to reconsider the observations already made on this subject. Arago first suggested that the polariscope should be used on the corona, but apparently did not anticipate any decided results. The principal observations since made are the following :-

1842.-Arago at Perpignan. Used a polariscope $a$ lunulis, that is, a double-image prism and crystal. He found the two images of complementary tints, the colour extending over the sky around the corona, the corona itself, and even over the disc of the moon.

1842.-Mauvais at Perpignan. Used a Savart's polariscope. He saw the bands very distinctly on the corona, and faintly on the moon itself. Their maximum of intensity corresponded with the horizontal position of the bands. Evidently he should have found another maximum when the bands were vertical.

Both this and the preceding observation show the existence of atmospheric polarisation extending even over the disc of the moon. Its plane must have been the same throughout, or Arago would have seen the different parts varying in tint. The maximum noticed by Mauvais shows that the plane must have been either vertical or horizontal, that is, not oblique.

1851.-Abbadie at Trocdeseckseverk. Inserted a plate of quartz between the object glass and eye-piece of his telescope, and applied a double refracting prism to the eye-piece as an analysis. He found the light of the corona strongly polarised, but saw no traces of colour on the moon. He was, however, troubled by clouds.

1851.-Dunkin at Christiania. Found no traces of polarisation, but was troubled by clouds.

I 85 I.-Carrington at Lilla-Idel. Used a Nicol's prism, but found no polarisation. 
1858.- Liais at Paranagua. Instrument used, a Savart's polariscope. He found the plane normal to the limb of the sun, and the intensity small, but greater than that of the moon.

$\mathrm{He}$ also remarks that the neutrat point of sky polarisation was in the neighbourhood of the sun, a statement difficult to comprehend, as the neutral points are commonly defined by their distance from the swn.

1860.--Secchi on Mont St. Michel. Used an Arago's polariscope, and found that the images were not of equal colour, and that one was elongated in one direction, the other in a direction perpendicular to it. This last appearance was probably imaginary, as the crystal in the polariscope would prevent the extinction of any polarised rays.

I860,- Pragmowski at Briviesca. Used a plate of right and left-handed quartz at the common focus of the object glass and eye-piece, and a Nicol's prism in the eye-piece. This combination should give two semicircles of complementary tints when the plane of polarisation is oblique to the line of junction of the quartz. Using a power of 22, placing the line of junction vertical, and bisecting thesun, he found the top and bottom alone of uniform tint, the two semicircles being very strongly coloured, one red, the other green. He thence inferred a radial polarisation. In reality, in this case, he should have found the sides alike, as well as the top and bottom, only faint yellow instead of purple, and the colours most strongly marked at angles of $45^{\circ}$.

I 868.- Campbell used a Savart's polariscope and found the bands strongly marked, having a maximum at $140^{\circ}$ from the vertex.

I 868.- Winter used a similar instrument, and, as a result, found the polarisation very strong, especially close to the sun.

1869. - Pickering at Mount Pleasant. The writer used an Arago's polariscope, and found the sky polarised close to the corona, the plane being the same on all sides of the sun.

1869.--Smith, at Eden Ridge, records a similar result obtained by a member of his party.

We see, therefore, that the results are very variable, the polarisation of the corona ${ }_{3}$ if any, is obscured by that of the sky, probably due to secondary reflection. It is therefore very desirable to use some means of neutralising this effect. One remedy is to place a double-image prism in front of the telescope, which thus superposes two images of the sky polarised at right angles. For observations on the sky no telescope should be used, or the light will be too much enfeebled. A Savart's polariscope is the most delicate instrument, but such a one as the Arago is more useful to determine just what portion of the light is polarised. The Nicol's prism and the doubleimage prism give such indefinite results, that little could be expected of them, and they have been tried by several observers without success. The best instrument to measure the intensity of the polarisation is the polarimeter, consisting of several glass plates, which can be set at an angle in front of a Savart, and the point of disappearance of the bands recorded. The absence of polarisation of the protuberances has been observed by Abbadie, Pragmowski, and others, and seems so well determined, their further examination is unnecessary.

EDWARD C. PICKERING
THE RESOURCES OF LA PLATA

The Mineral and other Resources of the Argentine Republic. Published by special authority of the National Government by Major I. Rickard, F.G.S. (London : Longmans and Co., 1870.)

MAJOR RICKARD has executed in a very creditable manner the task which the National Government deputed him to perform, and his volume will give its readers considerable insight into the vast material resources of the Argentine Republic. Hitherto La Plata, in spite of its name, has been regarded rather as a field for agricultural enterprise than as a source of mineral wealth; and the stories which were once current of mountains rich in precious metals have been forgotten in the details given by our countrymen of their successful farming in the pampas of the south. Various causes have combined to divert attention from the mineral riches of the country. The tedious contest with Lopez, only just concluded, and the turbulent character of the gauchos and Indian tribes, have checked the growth of confidence in the minds of emigrants or capitalists; and though the vigorous administration of President Sarmiento has already done much to remove these obstacles, some time must still elapse before investors will be persuaded that "the great Republic of the South" is likely to realise all the favourable vaticinations of which Major Rickard makes it the subject. What, however, has most retarded the progress of mining, and, indeed, of all industrial enterprise, in the Argentine Republic, has been the deficient population and the want of means of intercommunication and transport. Buenos Ayres and the other riverine provinces, where grazing is a pleasant and profitable pursuit, absorb nearly all the working power of the Republic, and at the present time not more than 2,687 persons are engaged upon any form of mining industry. If the reader will cast his eye over a map of the country (the absence of which in Major Rickard's book is a serious defect), he will see what a mere seratching of the soil can be effected by such a handful of men. Hence it is that very trifling results have hitherto been obtained from the few mines yet in operation, and that the processes for reducing the ore have remained defective and costly. The supplies drawn from the Argentine Republic produce no appreciable effect upon the metal markets of the world, and in popular estimation its exports solely consist of tallow, wool, and bides.

President Sarmiento, a man of no common discernment, is convinced that the substantial wealth of his country is to be found in its mineral resources, and, moreover, that they will provide the surest means for promoting rapid and extensive immigration. In their development is bound up the extension of commerce and the progress of agriculture. Had it not been for the discovery of gold, California might still have remained a vast cattle range to this day; and what is there to prevent La Plata, which can boast of the riches of Copiapo, Potosi, and Famatina, from rivalling her neighbour in wealth, population, and national importance?

The Argentine Republic is divided into fourteen provinces, and extends southwards from the Tropic of Capricorn to the 4oth parallel of latitude. Roughly speaking, the characteristics of the country admit of a two-fold division; the northern and eastern provinces being 